\title{
Analisis Pemanfaatan Program Gerakan Seribu Jamban di Kabupaten Lima Puluh Kota
}

\author{
Vina Novela ${ }^{1 *}$ \\ Prodi ilmu kesehatan masyarakat STIKes Fort de kock Bukittinggi \\ Email:vinanovela7271@gmail.com ${ }^{1)}$
}

\begin{abstract}
Abstrak
Masalah Sanitasi terutama kepemilikan Jamban di Indonesia masih menjadi masalah yang utama untuk diatasi, terutama akses Buang Air Besar. Secara nasional rumah tangga yang memiliki akses BAB baru mencapai 59\%, sedangkan di Kabupaten Lima Puluh Kota cakupan akses jamban hanya 55,48\%. Tujuan penelitian adalah diketahuinya gambaran perilaku masyarakat dalam pemanfaatan Program Seribu Jamban Di Kabupaten Lima Puluh Kota.Penelitian ini menggunakan metode kualitatif yang didukung dengan penelitian kuantitatif. Pengumpulan data kuantitatif dilakukan dengan menggunakan kuesioner terhadap 91 responden. Pengumpulan data kualitatif dilakukan dengan mewawancarai 9 orang informan terkait komponen input, proses output.Hasil analisis kuantitatif menunjukkan bahwa pengetahuan dan tindakan masyarakat dalam pemanfaatan jamban termasuk dalam kategori baik, namun keadaan lingkungan fisik rumah dan peran tenaga kesehatan di Kabupaten Lima Puluh Kota masih kurang baik.Sedangkan hasil analisis kualitatif menunjukkan bahwa kebijakan tentang program gerakan seribu Jamban sudah ada dalam bentuk SK Bupati.Dana dan SDM pelaksanaan program pada dasarnya belum mencukupi. i.Ketersediaan sarana tidak mencukupi untuk membangun jamban yang layak.Kegiatan sosialisasi dan peningkatan partisipasi masyarakat memiliki hambatan dalam pelaksanaannya.Monitoring dan evaluasi rutin dilakukan tapi petugas kesehatan masih sering tidak disiplin karena adanya tugas rangkap. Diharapkan kepada Dinas kesehatan dan Puskesmas untuk meningkatkan Monev dan dana insentif bagi kader aktif dan membuat program inovatif.
\end{abstract}

Kata kunci :Input,proses,output,Perilaku,Lingkungan Fisik

\begin{abstract}
The significant sanitation problem to be solved in Indonesia is the availability of toilet, especially toilet which is used for defecate. Nationally, the number of house holds with the access for defecate is only 59\%, Regency the access for toilet is only for 55,48\%. The purpose of this research is to know the behavior of the society in using the program for one thousand toilets at Lima Puluh Kota Regancy and to obtain the description of the implementation of one thousand toilet program at Lima Puluh Kota Regancy in 2015. This research is qualitative research design which is supported by quantittive research. Data is collected through interview with 9 interviewersto get the information about the implementation of one thousand toilets program at Lima Puluh Kota Regancy in 2015, starting from the input, process component, until out put component. The result of quantitative andqualitative analysis showed that the policy about one thousand toilets program is on the decree of head regancy. The cost of implementing this program is basiclly not enough. A number of human resources to run this program especially the sanitation is not sufficient. The availability of facility to build better toilet is not enough. The socialization and increasing of society participation to carry out this one thousand toilets program still have some obstacles in implementation. Monitoring and evaluation are done regularly but the health workers are indiscipline in their monitoring activities because they have double jobs and the insufficient number of health workers.
\end{abstract}

Keywords : Behavior, Input,Proccess,Output, , Physical Environment 


\section{PENDAHULUAN}

Lingkungan menjadi salah satu penyebab timbulnya masalah kesehatan masyarakat yang dipengaruhi oleh pertumbuhan penduduk dan teknologi sehingga mengakibatkan mobilitas penduduk semakin pesat serta lingkungan dan ruang gerak penduduk menjadi ancaman terhadap kesehatan lingkungan. Parameter tingkat kesehatan lingkungan antara lain penyediaan dan pemanfaatan tempat pembuangan kotoran dan cara buang kotoran manusia yang sehat. Penanganan pembuangan kotoran manusia yang tidak semestinya akan mencemari persediaan air, tanah, dan perumahan oleh kuman penyakit. ( Azwar,2000)

Undang - undang No 36 tahun 2009 tentang Kesehatan menyatakan bahwa upaya kesehatan lingkungan ditujukan untuk mewujudkan kualitas lingkungan yang sehat, baik fisik, kimia, biologi, maupun sosial yang memungkinkan setiap orang mencapai derajatkesehatan yang

Upaya sanitasi berdasarkan Keputusan Menteri Kesehatan RI Nomor 852/Menkes/SK/IX/2008 yang disebut Sanitasi Total Berbasis Masyarakat (STBM), yaitu : meliputi tidak Buang Air Besar (BAB) sembarangan, mencuci tangan pakai sabun, mengelola air minum dan makanan yang aman, mengelola sampah dengan benar mengelola limbah air rumah tanggadengan aman (Depkes RI, 2010) ${ }^{4}$. Sementara itu ketersediaan jamban keluarga atau rumah tangga ini dikatakan sehat bila keluarga memiliki dan menggunakan jamban leher angsa dengan tangki septik tank atau lubang penampung kotoran sebagai pembuangan akhir.

Data hasil Riset Kesehatan Dasar (Riskesdas) tahun 2010 secara nasional rumah tangga yang mempunyai dan menggunakan fasilitas $\mathrm{BAB}$ sendiri baru setinggi-tingginya. Pemerintah, pemerintah daerah dan masyarakat menjamin ketersediaan lingkungan yang sehat dan tidak mempunyai risiko buruk bagi kesehatan. Lingkungan sehat sebagaimana dimaksud mencakup lingkungan permukiman, tempat kerja, tempat rekreasi, serta tempat dan fasilitas umum (undangundang Kesehatan, 2009).

Sanitasi Total Berbasis Masyarakat (STBM) atau dikenal juga dengan nama Community Lead Total Sanitation (CLTS) merupakan program pemerintah dalam rangka memperkuat upaya pembudayaan hidup bersih dan sehat, mencegah penyebaran penyakit berbasis lingkungan, meningkatkan kemampuan masyarakat, serta mengimplementasikan komitmen pemerintah untuk meningkatkan akses air minum dan sanitasi dasar berkesinambungan dalam pencapaian Millenium Development Goals (MDGs) Tahun 2015 (Depkes RI, 2010).

$69,7 \%$ dan masih ada $15,6 \%$ rumah tangga yang tidak memiliki dan menggunakan fasilitas BAB. Sementara rumah tangga yang berada di pedesaan yang menggunakan fasilitas BAB sendiri baru mencapai 59\% dan masih ada 25,5\% rumah tangga yang tidak menggunakan fasilitas BAB. Sedangkan Sumatera Barat rumah tangga yang menggunakan fasilitas $\mathrm{BAB}$ sendiri baru $57,5 \%$ dan masih ada $25,3 \%$ lagi rumah tangga yang tidak memiliki dan menggunakan fasilitas $\mathrm{BAB}$. Rumah tangga yang memiliki tempat pembuangan tinja layak sesuai MDGs di sumatera Barat hanya $41,5 \%$. Ini menunjukkan masih sangat rendahnya kepemilikan dan penggunaan fasilitas $\mathrm{BAB}$ dan tempat pembuangan tinja yang layak di Sumatera Barat. (KEMENKES 2013).

Sesuai dengan data Kabupaten Lima puluh Kota jumlah penduduk yang sudah 
memiliki jamban pribadi baru 50,5 \% dan masyarakat yang belum menggunakan jamban pribadi sebanyak 49,5\%, yang menggunakan MCK umum baru 9,9\%, yang masih BAB sembarangan sebanyak 34,6\%, Selanjutnya yang masih BAB ke sungai atau danau sebanyak $9,9 \%$, sedangkan yang $\mathrm{BAB}$ ke parit sebanyak $1,3 \%$, yang menggunakan lubang sebanyak $2,3 \%$, dan yang BAB ke kebun sebanyak 7\% (AMPL Kab.Lima Puluh Kota, 2012).

Menyikapi permasalahan sanitasi tersebut terutama mengenai kepemilikan jamban yang memenuhi syarat kesehatan maka, Dinas Kesehatan bersama pemerintah Kabupaten Lima Puluh Kota membuat sebuah program yang tujuan utamanya adalah terpenuhinya kebutuhan masyarakat terhadap akses pembuangan Air Besar yang memnuhi syarat kesehatan. Program ini dinamakan gerakan seribu jamban yang diperuntukkan bagi masyarakat tidak mampu di daerah dengan tingkat diare yang tinggi dan cakupan pemakaian jamban yang masih rendah.

Survey dilakukan pada salah satu Puskesmas yaitu wilayah kerja Puskesmas Taram, yang mana dari 90 closet yang telah dibagikan kepada masyarakat di nagari Batu balang baru 45 yang terpasang. Begitu juga dengan wilayah kerja Puskesmas Batu Ampa dari 88 Closet yang dibagikan hanya $50 \mathrm{KK}$ yang terpicu untuk memasang.

Hasil wawancara, pada saat melakukan studi pendahuluan dengan tenaga Kesling di salah satu Puskesmas Kabupaten Lima Puluh kota, diketahui bahwa pelaksanaan program seribu jamban sudah merupakan salah satu upaya dinas kesehatan dan pemerintah daerah untuk meningkatkan derajat kesehatan terutama untuk perbaikan perilaku masyarakat sehingga mempunyai dan memanfaatkan akses terhadap jamban sehat. Pembagian jamban yang dilakukan oleh puskesmas ternyata tidak semua masyarakat merespon dan menerima dengan baik. Dari jamban yang dibagikan ke masing-masing jorong baru dipasang 56\% jamban dan itupun masih sangat sederhana dan pembuangan tinja masih ke kolam dan sebagian ada lobang tinja tanpa pipa hawa.hal ini disebabkan oleh bantuan hanya berupa closed dengan anggaran dana 35.000/KK sedangkan dana pendamping untuk membangun jamban lebih besar.

Setelah dilakukan wawancara kepada 10 orang KK yang mendapat closet gratis di wilayah kerja Puskesmas Taram dari Program gerakan seribu jamban yang menjadi penyebab tidak dibangunnya jamban karena tidak ada biaya untuk pemasangan dan membuat septiktank, 4 orang KK menyatakan bahwa mereka mempunyai kolam ikan, sehingga mereka menggunakan kolam untuk tempat BAB. Walaupun telah dibangun jamban namun tidak ada dimonitoring oleh pihak Puskesmas. Sementara 6 orang KK lainnya menyatakan bahwa mereka tidak mempunyai sumur pribadi sebagai sumber Air untuk menggelontor tapi mereka menggunakan MCK umum seperti sumur Mushalla dan mesjid.

Tujuan penelitian ini adalah Menganalisis pemanfaatan Program Gerakan Seribu Jamban di Kabupaten Lima Puluh Kota.

\section{METODE PENELITIAN}

Penelitian ini merupakan deskriptif analitik dengan pendekatan kuantitatif dan dilanjutkan dengan kualitatif untuk mendapatkan gambaran program lebih dalam. Penelitian dilakukan mulai bulan Maret 2015 s/d September $2015 \quad$ di Kabupaten Lima Puluh Kota.

\section{HASIL DAN PEMBAHASAN A.Penelitian Kantitatif 1. Cakupan Rumah SehatPada tahun 2012 jumlah rumah yang ada di Kabupaten Lima Puluh Kota adalah 88.257 buah dan yang}


memenuhi syarat 48.681 rumah $(55,16 \%)$ dan yang belum memenuhi syarat 39.576 buah (44,84\%). Pada tahun 2013 terjadi peningkatan rumah sehat menjadi 62.338 buah $(70,53 \%)$.

\section{Cakupan Air Bersih}

Air minum yang didistribusikan oleh PDAM dengan target tahun ini adalah minimal 90\%. Persentase penduduk yang memiliki akses terhadap air minum yang berkualitas dengan target sebesar $75 \%$ pencapaian baru $71,47 \%$.

\section{Cakupan Jamban Keluarga}

Secara nasional, persentase rumah tangga menurut akses terhadap pembuangan tinja layak sesuai MDGs adalah 55,5\%. Di Kabupaten Lima Puluh Kota akses jamban baru mencapai $61,14 \%$ dengan target $75 \%$.

\section{Sumber Daya Dinas Kesehatan}

\section{Puskesmas dan Jaringannya}

Puskesmas merupakan unit pelaksana teknis dari Dinas Kesehatan Kabupaten/Kota yang berada diwilayah Kecamatan dan melaksanakan tugas operasional pembangunan kesehatan. Pembangunan Puskesmas di tiap Kecamatan memiliki peran yang sangat penting dalam memelihara kesehatan masyarakat.

Pada tahun 2013 Kabupaten Lima Puluh Kota memiliki 22 puskesmas yang tersebar di 13 kecamatan.Pada tabel 5.2 berikut ini dapat kita lihat rasionya terhadap jumlah penduduk per kecamatan

\section{Kondisi Lingkungan}

Lingkungan Fisik dan Biologis masih belum memadai di wilayah kerja Puskesmas Taram, ini ditandai dengan masih tingginya angka infeksi dan penyakit kulit di wilayah kerja.Kondisi lingkungan ditandai dari cakupan beberapa indikator lingkungan sehat antara lain:

\section{a. Cakupan rumah Sehat}

Pada tahun 2014 jumlah rumah yang memenuhi syarat baru mencapai $47 \%$ dan yang tidak memenuhi syarat sebanyak 53\%. Hal ini masih sangat jauh dari target yang seharusnya $75 \%$.

\section{b. Cakupan Air Bersih}

Sumber air minum yang digunakan masyarakat adalah sumber air minum terlindung (air kemasan, ledeng, pompa,mata air terlindung dan air hujan). Dari 600 rumah yang diperiksa sumber airnya ada sebanyak 253(47\%) yang memenuhi syarat dan yang tidak memenuhi syarat sebanyak 347(53\%).

c. Cakupan Jamban Keluarga

Jenis sarana yang dipakai untuk BAB umumnya leher angsa, plengsengan, cemplung atau cubluk.Dari 600 rumah yang diperiksa ada sebanyak 253 rumah yang memiliki jamban. Yang memiliki jamban sehat ada sebanyak $105(47 \%)$ dan sebanyak 148 tidak memenuhi syarat(53\%).

\section{Analisis Univariat}

Tabel 1.

Distribusi Frekuensi Karakteristik Responden

\begin{tabular}{lll}
\hline Variabel & n & $\%$
\end{tabular}

Pendidikan

$\begin{array}{lcr}\text { - Tidak sekolah } & 14 & 15.4 \% \\ \text { - SD } & 33 & 33,6 \\ \text { - SMP } & 32 & 35,2 \\ \text {-SMA } & 12 & 13,2\end{array}$

Pekerjaan

\begin{tabular}{lll}
\hline - Tidak & 12 & 13,2 \\
Bekerja/IRT & 77 & 84,6 \\
\hline
\end{tabular}




\begin{tabular}{lcc}
\hline - Petani & 2 & 2,2 \\
- Pedagang & & \\
\hline Pendapatan & & \\
\hline$-<1.200 .000$ & 72 & 79,1 \\
$-\geq 1.200 .000$ & 19 & 20,9
\end{tabular}

Tabel 1 menunjukkan bahwa tingkat pendidikan responden $35,2 \%$ SMP dan ada sebanyak $15,4 \%$ yang tidak sekolah, pekerjaan responden sebagian besar adalah petani $(84,6 \%)$ dan pendapatan rata-rata responden $<1.200 .000(79,1 \%)$

Tabel 2.

Distribusi Frekuensi Variabel Independen dan Dependen

\begin{tabular}{lll}
\hline \multicolumn{1}{c}{ Variabel } & n & $\%$ \\
\hline Pengetahuan & & \\
\hline
\end{tabular}

$\begin{array}{lcc}\text { - Rendah } & 21 & 23,1 \\ \text { - Tinggi } & 70 & 76,9\end{array}$

\begin{tabular}{lll}
\hline Tindakan & & \\
\hline - Kurang Baik & 28 & 30,8 \\
- Baik & 63 & 69,2
\end{tabular}

\begin{tabular}{lll}
\hline Lingkungan Fisik & & \\
\hline - Tidak layak & 25 & 27,5 \\
- Layak & 66 & 72,5 \\
\hline
\end{tabular}

Peran tenaga

Kesehatan

\begin{tabular}{lll}
\hline - Kurang & 11 & 12,1 \\
- Baik & 80 & 87,9 \\
\hline Pemanfaatan & & \\
jamban & & \\
\hline - Dimanfaatkan & 70 & 76,9 \\
- Tidak & 21 & 23,1 \\
$\quad$ Dimanfaatkan & & \\
\hline
\end{tabular}

Dari tabel 2 diketahui bahwa 76,9\% responden sudah memiliki pengetahuan tinggi tentang jamban sehat, 69,2\% memiliki tindakan yang baik, $72,5 \%$ mempunyai lingkungan fisik yang layak untuk pembangunan jamban, $87,9 \%$ peran tenaga kesehatan baik dan 76,9\% pemanfaatan program seribu jamban sudah terlaksana.

Hasil penelitian melalui wawancara terhadap komponen input menggambarkan bahwa Kebijakan yang telah ada dikeluarkan oleh pemerintah Kabupaten Lima Puluh Kota itu hanya berupa SK bupati saja yang menyatakan bahwa penetapan penerima bantuan dari Program seribu Jamban dari tahun anggaran 2012-2014. Disamping itu berdasarkan observasi masih ada bantuan yang sudah diterima belum dipasang oleh masyarakat sesuai dengan komitmen awal masyarakat.

Hasil penelitian yang dilakukan oleh fahmi ridho tahun 2013 menyatakan bahwa program seribu jamban di Kecamatan Baruah Gunuang belum terlaksana dengan baik karena sikap masyarakat yang beranggapan program pemerintah akan terus terlaksana walaupun tidak ada partisipasi dari masyarakat karena anggarannya sudah ada.begitu juga penelitian yang dilakukan oleh Roza tahun 2015 bahwa kebijakan program seribu jamban belum memberikan dampak dan hasil yang sesuai target, walaupun sudah disosialisasikan namun sikap dan kemampuan masyarakat dari segi ekonomi tidak mendukung pelaksanaan program.

Kebijakan nasional untuk upaya sanitasi berdasarkan pada Keputusan Menteri Kesehatan RI Nomor 852/Menkes/SK/IX/2008 yang disebut Sanitasi Total Berbasis Masyarakat (STBM), yaitu meliputi tidak Buang Air Besar (BAB) sembarangan, mencuci tangan pakai sabun, mengelola air minum dan makanan yang aman, mengelola sampah dengan benar mengelola limbah air rumah tanggadengan aman.Sesuai dengan tujuan dan sasaran serta kebijakan yang telah ditetapkan maka strategi yang dirumuskan untuk pelaksanaan program 
yaitu:1)Pemberdayaan

.(Kemenkes,RI.2013)

Kebijakan tentang Program Gerakan

Seribu Jamban di Kabupaten Lima Puluh Kota belum terlaksana dengan baik di beberapa wilayah dan sudah terlaksana dengan baik disebagian wilayah seperti pada wilayah Koto Tinggi yang berhasil mendapatkan penghargaan atas keberhasilan Puskesmas dan pemerintah nagarinya dalam meningkatkan keberhasilan program. Hal ini tentunya menjadi pelajaran dan acuan oleh wilayah lain yang ada di Kabupaten Lima Puluh Kota bagaimana supaya dapat menggerakkan masyarakat dengan keterlibatan aktif semua sektor, mulai dari puskesmas sampai ke Nagari. Sehingga dengan aktifnya tenaga kesehatan dan kuatnya dukungan dari llintas sektor maka kebijakan yang telah dikeluarkan untuk meningkatkan status kesehatan masyarakat itu akan berhasil dan berjalan dengan baik.

Selain itu dari segi dana diketahui bahwa ketersediaan Dana atau anggaran untuk saat ini tidak mencukupi untuk pelaksanaan program seribu jamban Di Kabupaten Lima Puluh Kota. Ketersediaan dana dari APBD hanya untuk closet saja dengan dana Rp.35.000 sementara kebutuhan dana untuk membangun jamban yang memenuhi syarat lebih besar, dan itu diharapkan dari swadaya masyarakat penerima bantuan. Hal ini tentu tidak menunjang keluarga untuk dapat membangun jamban yang utuh dan bisa dimanfaatkan untuk BAB dan dapat menghambat keberhasilan program.

Hal ini sejalan dengan penelitian Elia

Roza tentang analisis faktor yang berhubungan dengan Pemanfaatan program seribu jamban di Wilayah puskesmas Baruah Gunuang Kabupaten Lima Puluh Kota tahun 2015 bahwa tidak tercapainya target dari program seribu jamban yaitu dari 45 closet yang dibagikan hanya $52 \%$ yang berhasil dipasang disebabkan oleh kurangnya tenaga sanitarian dipuskesmas atau SDM yang akan melaksanakan program kesling mempunyai tugas rangkap.

Hasil penelitian ini juga sejalan dengan penelitian Muhammad Jauhar, dkk tentang perilaku masyarakat dalam penggunaan Jamban dan kondisi jamban pasca metode pemicuan di Desa Pamulihan Kecamatan Cisurupan Kabupaten Garut bahwa program pemicuan tidak berhasil karena kurangnya tenaga kesehatan yang terampil untuk memberikan pemicuan sehingga tidak menarik perhatian masyarakat dan tidak merubah perilaku masyarakat.

Wawancara terkait sarana untuk penunjang kegiatan program seribu jamban menggambarkan belum maksimal ketersediaannya terutama sarana pokok untuk pembangunan jamban oleh masyarakat. Hal ini terlihat dari jenis bantuan sarana yang diberikan hanya berupa closet saja, sementara untuk membangun jamban keluarga yang memenuhi syarat walaupun dalam bentuk sederhana saja itu memerlukan sarana lain seperti pipa, batu,atap, semen. Ini yang menjadi kendala bagi masyarakat untuk membangun jamban karena sarana penunjang lain itu dari swadaya masyarakat, sementara masyarakat yang mendapat bantuan closet rata-rata tingkat pendapatan keluarganya rendah.

Sosialisasi adalah suatu proses aktif dimana pengambil kebijakan atau pelaksana program turun ke masyarakat untuk memberikan informasi dan pemahaman sehingga masyarakat yang diberdayakan harus berperan aktif (berpartisipasi) dalam program Gerakan Seribu Jamban. Hasil wawancara mengenai Sosialisasi untuk kegiatan program seribu jamban sudah dilaksanakan kepada lintas sektor nagari dan masyarakat yang akan menerima bantuan bersama dengan puskesmas dan dinas kesehatan. Sosialisasi dilakukan selain untuk menggambarkan program dan bantuan 
dalam program juga untuk meningkatkan partisipasi masyarakat dan membangun komitmen masyarakat sasaran dalam membangun jamban dari closet yang nantinya akan didistribusikan.Kegiatan sosialisasi ini banyak menghadapi kendala terutama dari kehadiran masyarakat untuk menghadiri sosialisasi, sangat susah mengumpulkan masyarakat untuk dapat memberikan informasi dan pemahaman, selain itu peran pemerintah nagari yang sangat rendah untuk mengajak masyarakatnya berkumpul. Satu hal lagi yang menjadi problem dalam mengumpulkan masyarakat adalah budaya adanya bantuan transportasi atas kehadiran masyarakat dalam kegiatan sosialisai, dalam kegiatan ini tidak adanya bantuan transportasi atas kehadiran mereka sehingga motivasi masyarakat untuk meluangkan waktu menghadiri sosialisasi rendah. Tidak hanya tenaga kesehatan selaku fasilitator dan pelaksana program tetapi peran pemerintah nagari sangat diharapkan dan sangat menunjang keberhasilan kegiatan. komitmen dari semua unsur kegiatan program akan terlaksana dengan baik.

Kegiatan monitoring berdasarkan hasil wawancara dengan Dinas Kesehatan dan Puskesmas diperoleh informasi bahwa kegiatan monitoring dan evaluasi selalu rutin diadakan. Monitoring dilakukan tiap bulan,dan dilakukan pencatatan untuk pelaporan.Untuk evaluasi sendiri pelaksanaannya dilakukan sekali tiga bulan, melalui evaluasi ini tentunya bisa dilihat bagaimana pencapaian program saat ini, sehingga untuk ke depannya dapat disusun kembali rencana-rencana kegiatan yang akan dilaksanakan dalam upaya peningkatan partisipasi masyarakat untuk pembangunan jamban.

Dari evaluasi didapatkan informasi bahwa program ini masih belum mencapai target sebagaimana yang direncanakan, karena masih banyak kendala yang dihadapi dilapangan terutama dari segi dana, sumber air dan yang paling mendasar adalah kebiasaan masyarakat untuk BAB yang menggunakan kolam/tobek serta motivasi masyarakat yang rendah untuk berperilaku hidup bersih dan sehat. Sehingga dengan demikian harapan program seribu jamban untuk menjadikan Kabupaten Lima Puluh Kota bebas dari Buang Air Besar Sembarangan tidak bisa tercapai.

Komponen output dalam penelitian ini adalah dibangun dan dimanfaatkannya jamban oleh keluarga sebagai sarana BAB.Aspek pemanfaatan dan pembangunan ini dinilai dengan melihat pengaruh dari beberapa variabel yaitu : pengetahuan, Tindakan, lingkungan fisik, dan peran tenaga kesehatan.

Dari hasil wawancara dan analisa kuantitatif kuesioner maka dapat diketahui bahwa Program Gerakan Seribu Jamban di Kabupaten Lima Puluh Kota sudah berhasil dilaksanakan disebagian besar wilayah kerja Puskesmas bahkan ada penghargaan yang diraih oleh Puskesmas Koto tinggi melalui program ini karena lebih dari $100 \%$ berhasil membangun jamban dan memicu masyarakat untuk berpartisipasi, namun masih ada wilayah yang belum memasang closet dan memanfaatkan jamban untuk sarana BAB keluarga yang mana tingkat pencapaian rata-rata masyarakat yang memasang closet sudah mencapai 90\% namun pemanfaatannya masih dibawah $75 \%$, hal ini disebabkan karena keterbatasan dana dari masyarakat penerima bantuan untuk melengkapi bangunan jamban dan sumber air yang tidak ada dirumahnya,serta tugas rangkap tenaga kesehatan selaku fasilitator dan pengawas kegiatan terutama sanitarian dalam program ini.

Dari hasil analisis data juga diperoleh informasi bahwa pemanfaatan jamban yang rendah oleh masyarakat disebabkan oleh tingkat pendapatan Rumah Tangga yang rata-rata rendah yaitu $72 \%$ dari 91 
masyarakat yang menjadi sampel, perilaku masyarakat yang kurang baik dalam penggunaan jamban serta keadaan lingkungan fisik rumah yang tidak layak untuk pembangunan jamban yang memenuhi syarat seperti ketersediaan Air serta peran tenaga kesehatan.

Berdasarkan hasil analisa pengetahuan masyarakat saat ini sudah lebih baik mengenai kesehatan terutama mengenai jamban yang memenuhi syarat kesehatan, dimana 79,6\% masyarakat sudah memiliki pengetahuan yang tinggi tentang pentingnya jamban sehat hal ini karena banyak media yang bisa memberikan informasi saat ini walaupun peran tenaga kesehatan mulai kurang, namun perilaku dan kebiasaan masyarakatlah yang menyebabkan mereka tidak menerapkan perilaku sehat dalam kehidupannya.

\section{SIMPULAN}

Kebijakan tentang program seribu jamban telah ada dan telah dikeluarkannya dalam bentuk SK Bupati Lima Puluh Kota tentang penetapan penerima hibah Kloset untuk tahun anggaran 2013/2014.Dana untuk pelaksanaan kegiatan program seribu jamban ini tidak mencukupi untuk pencapaian target.Sumber Daya Manusia untuk pengelola program seribu jamban itu masih belum memadai karena SDM yang tersedia untuk pengelola program langsung tenaga sanitarian, sarana yang disediakan hanya closet sedangkan sarana lain untuk membangun jamban dari swadaya masyarakat.

Kegiatan sosialisasi sudah dilaksanakan kepada lintas sektor nagari dan masyarakat namun banyak menghadapi kendala. Monitoring dan evaluasi selalu dilakukan oleh tenaga sanitarian dilapangan 1 kali dalam sebulan. Dari hasil evaluasi kegiatan program seribu jamban pelaksanaannnya belum cukup baik. Sebaiknya untuk meningkatkan motivasi dan partisipasi masyraakat dibentuk kelompok arisan jamban yang dikelola oleh masyarakat.

\section{SARAN}

Diharapkan dinas kesehatan membentuk kader kesling untuk operasional kegiatan program kesling dilapangan, sehingga tenaga kesehatan atau sanitarian dipuskesmas tidak lagi harus turun untuk memonitoring kegiatan tetapi hanya menerima laporan dari kader kesling yang telah dilatih tersebut. Untuk lancarnya kegiatan kader kesling dilapangan maka disediakanlah anggaran dana insentif bagi kader aktif demi meningkatkan motivasi kader dalam bekerja.

\section{DAFTAR PUSTAKA}

Azwar,A. 2000. Pengantar Ilmu Kesehatan Lingkungan. Mutiara Sumber Widya

Depkes RI, 2010. Pedoman Penggunaan dan Pemeliharaan Sarana PAB dan PLB , Ditjen PPM dan PPLP,Jakarta.

Kemenkes RI, 2013. Riset kesehatan Dasar RI tahun 2103

Pokja AMPL Kabupaten Lima Puluh Kota, 2012. Buku Putih Sanitasi kabupaten Lima Puluh Kota.

Profil Kesehatan Dinkes Kabupaten Lima Puluh Kota Tahun 2014

Kemenkes RI,2013. Kurikulum dan Modul Pelatihan fasilitator Pemberdayaan Masyarakat Bidang kesehatan.Ditjen PPM dan PL: Jakarta

Roza,E. Analisis Pemanfaatan program Seribu Jamban Di Wilayah Kerja Puskesmas Baruh Gunng Kecamatan Bukit Barisan tahun 
2015.Skripsi.Ilmu

Masyarakat(FDK)
Kesehatan

Jauhar ,M, Ahmad Yamin, Karwati. Perilaku masyarakat dalam penggunaan Jamban dan kondisi jamban pasca metode pemicuan di Desa Pamulihan Kecamatan Cisurupan Kabupaten Ga.Tesis.Fakultas Kesehatan Masyarakat.(UNDIP).jurnal kesehatan 2012: 65-68.

Depkes RI, 2013.Modul Materi Advokasi Sanitasi total berbasis masyarakat,Ditjen PPM dan PL: Jakarta.

Dainur Malik, 2002.Dasar-dasar kesehatan Lingkungan. PT Citra Aditya Bhakti.Jakarta

Edberg,M. 2010. Kesehatan Masyarakat teori sosial dan perilaku. EGC.Jakarta

Fahmi Ridho,2014. Faktor Faktor Yang Berhubungan Dengan Partisipasi Keluarga Dalam Kepemilikan Jamban Sehat di Jorong Tobek Godang Wilayah Kerja Puskesmas Baruah Gunuang Kecamatan Bukik Barisan Kabupaten Lima Puluh Kota Tahun 2014

Idrios, 2012. Faktor-faktor yang berhubungan dengan penggunaan jamban sehat di Jorong Suayan Randah Nagari Batu Ampa, Kecamatan Akabiluru tahun 2012.

Kemenkes RI, 2011.Modul Stop Buang Air Besar Sembarangan program PAMSIMAS. Ditjen PPM dan PL: Jakarta

Leni Setiawati. 2012. Evaluasi Program STBM dalam kepemilikan Jamban di Kecamatan Tinangkung Kabupaten Bagai kepulauan propinsi Sulawesi Tengah Tahun 2012
Notoatmodjo, S. 2003, Prinsip-prinsip dasar Ilmu Kesehatan Masyarakat. RinekaCipta: Jakarta.

Sugiyono, 2008, Metode Penelitian Administrasi. Alfabeta.Bandung

Soeparman, 2002. Pembuangan Tinja dan Limbah cair,EGC.Jakarta

Wilya,2013.Hubunganpengetahuan,perilaku danlingkungandengankepemilikanjam ban di wilayahkerjaPuskesmasPakanRabaaK abupaten Lima Puluh Kota tahun 2013 
